\title{
Pendampingan Praktik Penyelenggaraan Jenazah Melalui Metode Explicit Intruction di SMA Ma'arif NU Pandaan
}

\author{
Achmad Yusuf, Intan Robi'ah \\ Universitas Yudharta Pasuruan \\ achysf@yudharta.ac.id, intanrobiah13@gmail.com
}

\begin{abstract}
:
This mentoring aims to provide knowledge and learning and experience directly to all students in organizing body management at SMA Maarif NU Pandaan. This accompaniment uses PAR debit via explicit instruction method. The results of this mentoring can increase the understanding of learners both from the theory and practical side, skills in organizing the body through explicit intruction. Improved process is known through the activities of students in the training and implementation of assistance by activities, while the increase of results can be known through student learning Achievement in the practice of the bodies of both individuals and groups.
\end{abstract}

Keywords: management of dead body, explicit instruction

\section{Pendahuluan}

Dalam historisnya, SMA ini didirikan oleh karangan ulama' (NU) Nahdhotul Ulama' yang berasaskan ahlussunnah wal jama'ah, perkiraan tahun 1960-an dengan nama Pendidikan Guru Agama (PGA), sehingga nama lengkapnya SMA ini Pendidikan Agama Islam Lengkap Nahdhotul Ulama' (PGALNU), hal ini karena berada di bawah Nahdhotul Ulama'. Perubahan dilakukan Departemen Agama tahun 1980 pada semua lembaga pendidikan yang bernama PGA (dikelola lembaga swasta) agar berganti nama pendidikan Guru Agama yang mulanya 4 tahun berganti baju menjadi Sekolah Menengah Pertama (SMP), sedangkan Pendidikan Guru Agama 6 tahun menjadi Sekolah Menengah Atas (SMA). Dan saat ini SMA menjadi sekolah kita karena dulunya pada jenjang Pendidikan Guru Agama 6 tahun, dengan tambahan Maarif NU Pandaan dikarenakan tetap dalan naungan yayasan pendidikan Nahdotul Ulama' dan bertempat dikecamatan Pandaan.

Dari sisi fasilitas, SMA ini memiliki system pelajaran yang berbasis ICT, 


\section{2 | Pendampingan Praktik Penyelenggaraan Jenazah ...}

meskipun berbasis teknologi, nuansa keislaman masih tetap melekat, karena sebagai budaya/caracter dari SMA Maarif NU Pandaan yang didirikan oleh ulama' yang berdedikasi tinggi dalam mendirikan sekolah ini untuk kemaslahatan umat. SMA menjadi salah satu tujuan masyarakat Pandaan dan sekitarnya sebagai lembaga yang dapat mengantarkan putra/putrinya mendapatkan dua hal yang tidak terpisahkan yaitu pengetahuan agama dan umum, bahasanya fi ad-dun yaa has anal wafil a-khiroti hasanah. Selain itu SMA Maarif NU Pandaan saat ini menjadi salah satu unggulan sekolah di sekitar masyarakat Pandaan yang bernuansa pesantren yang sesuai dengan keinginan wali murid yaitu menginginkan putra/putrinya menjadi manusia yang dapat menyeimbangkan antara sains teknology dan IMTAQ dalam kehidupan sehari-hari. Untuk mewujudkan keinginan tersebut, SMA Ma'arif NU Pandaan membekali peserta didik dengan Ilmu Pendidikan Islam baik dari sisi teori maupun praktik. Namun berdasarkan data empiris dari sisi praktik ubudiyah/agamanya kurang efektif, apalagi dalam konteks yang berkaitan dengan sosial masyarakat. hal ini berdasarkan hasil analisis bahwa minimnya praktik penyelenggaraan Jenazah. Dalam konteks ini dampingan bertujuan untuk menerapkan penyelenggaraan Jenazah melalui explicit intruction di SMA Ma'arif NU Pandaan.

Dampingan kegiatan praktek penyelenggaraan jenazah melalui metode explicit intruction bertujuan agar siswa-siswi SMA Ma'arif NU Pandaan tidak hanya tahu tetapi bisa mempraktikkan penyelenggaraan jenazah melalui metode explicit intruction serta dapat memberikan kontribusi dalam kehidupan masyarakat.

\section{Metode}

Metode yang digunakan dalam kegiatan dampingan ini adalah Strategi Participatory Action Research melalui metode explicit intruction. Explisit intruction merupakan suatu pola yang digunakan sebagai pedoman dalam pembelajaran.(Ceri Riyana, 2012) Menurut Archer dan Hughes, "model Explicit Intruction adalah salah satu pendekatan mengajar yang dirancang khusus untuk 
menunjang proses belajar siswa".(Huda, 2013) Menurut Kardi Explicit Instruction adalah model yang berbentuk ceramah, demonstrasi, pelatihan atau praktik, dan kerja kelompok. Model ini juga dapat digunakan untuk menyampaikan pelajaran yang ditranspormasikan langsung oleh guru kepada siswa. Kemudian Anurrahman mengemukakan bahwa Explicit Intruction atau yang dikenal sebagai pengajaran langsung merupakan suatu model dimana kegiatan terfokus pada aktivitas-aktivitas akademik sehingga di dalam implementasi kegiatan pembelajaran guru melakukan kontrol yang ketat terhadap kemajuan siswa, pendayagunaan waktu serta iklim kelas yang dikontrol secara ketat pula.Model Explicit Intraction (EI) adalah suatu pendekatan mengajar yang dapat membantu siswa dalam mempelajari keterampilan dasar dan memperoleh informasi yang dapat diajarkan selangkah demi selangkah. Model ini pertama kali diperkenalkan oleh Rosenshine dan Steven pada tahun 1986.(Qirana, 2008) Metode explicit instruction merupakan "cara penyajian pelajaran dengan memperagakan atau mempertunjukan kepada siswa suatu proses, situasi, atau benda tertentu yang sedang dipelajari, baik sebenarnya atau tiruan, yang sering disertakai dengan penjelasan lisan". Istilah lain dari model explicit instruction antara lain : training model, active teaching model, mastery teac hing, direct instruction atau model pengajaran langsung". Berdasarkan uraian di atas, maka dapat disimpulkan bahwa model Explicit Intruction merupakan suatu pendekatan atau model pembelajaran yang dirancang untuk mengembangkan belajar siswa tentang pengetahuan prosedur dan pengetahuan deklaratif sehingga agar siswa dapat memahami serta benar-benar mengetahui pengetahuan secara menyeluruh dan aktif dalam suatu pembelajaran dengan pola selangkah demi selangkah.Sohimin mengemukakan langkah-langkah pembelajaran Explicit Intruction, yakni sebagai berikut:

a. Menyampaikan kompetensi atau tujuan pembelajaran dan mempersiapkan peserta dampingan.

b. Mendemonstrasikan pengetahuan dan ketrampilan

c. Membimbing praktik dan pelatihan. 
214 | Pendampingan Praktik Penyelenggaraan Jenazah ...

d. Mengecek pemahaman siswa dan memberi umpan balik.

e. Memberikan kesempatan kepada siswa untuk latihan lanjutan

f. Kesimpulan.

Adapun tahapan dalam pelaksanaan pendampingan dalam kegiatan ini meliputi:

1. Tahap persiapan

Pada persiapan ini kegiatan dampingan akan dilakukan dengan fase-fase berikut; (a) Orientasi, (b) Presentasi, (c) Penyajian materi, (d) Latihan terstruktur, dan (e) Latihan terbimbing. Kegiatan dampingan ini dilaksanakan pada bulan Januari-Februari 2020, kegiatan ini dilaksanakan oleh dosen dan mahasiswa secara berkolaborasi di SMA Maarif NU Pandaan. Kegiatan dampingan ini juga melibatkan seluruh guru PAI di SMA Maarif NU Pandaan sekaligus menjadi guru pamong pada pendamping. Peserta dampingan pada kegiatan ini kelas XI IPA $1,2,3,4$, dan 5 .

2. Pelaksanaan Kegiatan

Kegiatan dampingan penyelenggaraan Jenazah ini dengan metode Explicit Intruction dilaksanakan dengan fase-fase sebagai berikut;

a) Orientasi, Pada fase ini orientasi yang diberikan dampingan dalam bentuk: 1) kegiatan pendahuluan untuk mengetahui pengetahuan yang relevan dengan pengetahuan tentang kewajiban terhadap jenazah yang telah dimiliki oleh peserta; (2) mendiskusikan atau menginformasikan tujuan tentang pendampingan penyelenggaraan Jenazah;(3) memberikan penjelasan/arahan mengenai kegiatan dampingan yang dilakukan tentang kewajiban seorang muslim dalam penyelenggaran Jenazah; (4) menginformasikan materi/konsep penyelenggaraan Jenazah yang dilakukan selama pembelajaran; dan (5) menginformasikan kerangka pelajaran.

b) Presentasi, Pada fase ini pendamping menyajikan materi pembelajaran baik yang berkaitan dengan pengetahuan tentang pengurusan penyelenggaraan 
Jenazah serta pengetahuan praktik maupun keterampilan tentang penyelenggaran Jenazah.

c) Penyajian materi dapat berupa: (1) penyajian materi dalam langkah-langkah kecil sehingga materi dapat dikuasai siswa dalam waktu relatif pendek; (2) pemberian contoh-contoh konsep; (3) pemodelan atau peragaan keterampilan dengan cara demonstrasi atau penjelasan langkah-langkah kerja terhadap tugas; dan (4) menjelaskan ulang hal-hal yang sulit.

d) Latihan terstruktur. Pada fase ini pendamping memandu siswa untuk melakukan praktik penyelenggaraan Jenazah. Pada saat ini pendamping memberikan umpan balik dan penguatan terhadap respon siswa yang benar serta mengoreksi respon siswa yang salah

Latihan terbimbing. Pada fase ini pendamping memberikan kesempatan kepada peserta dampingan untuk berlatih apa yang telah dijelaskan pengetahuan tentang penyelenggaraan Jenazah. Selain itu pada fase ini pendamping juga dapat memberikan penilaian terhadap pengetahuan, proses selama praktik penyelenggaraan berlangsung. Pada fase ini peran pendamping adalah memonitor dan memberikan bimbingan jika diperlukan.

\section{Hasil dan Diskusi}

Adapun lokasi pengabdian di SMA Maarif NU Pandaan, tempat ini dipilih dikarenakan di sekolah ini ada mahasiswa melaksanakan praktikum serta sudah ada peralatan sebagai salah satu alat penunjang kegiatan, selain itu kepala sekolahnya merupakan salah satu tokoh agama di daerah tersebut, disini juga baru digiatkan kegiatan tentang penanaman karakter berbasis keagamaan (dilakukan satu minggu sekali) khusus yang beragama Islam diajarkan tentang bagaimana tatacara bertoharoh, sholat yang benar menurut ajaran Islam sampai ke praktek penyelenggaraan jenazah. Kegiatan ini diikuti oleh para peserta baik guru, staf dan juga para murid yang mengikuti kegiatan ini di harapkan dapat mengejarkan kepada masyarakat dimana mereka tinggal. 
216 | Pendampingan Praktik Penyelenggaraan Jenazah ...

Kegiatan pengabdian kepada masyarakat (PKM) ini dilakukan secara berkolaborasi antara mahasiswa dosen, dan Guru Pendidikan Agama Islam di SMA Maarif NU Pandaan. Peserta yang terlibat dalam kegiatan pengabdian ini adalah seluruh siswa SMA Maarif NU Pandaan, dampingan ini bertujuan untuk menerapkan teori-teori yang telah di peroleh serta skill yang sudah di pelajari sebelumnya dengan menyesuaikan keadaan yang ada dilapangan, pada kegiatan ini guru pamong memberikan pengarahan kepada mahasiswa mengenai prangkat pembelajaran yang harus disiapkan sebelum melakukan praktik pengalaman lapangan secara terbimbing.

Pendampingan ini dilakukan di SMA Maarif NU Pandaan dengan metode explicit instruction ini terbagi menjadi tiga sesi, pertama menyampaikan materi yang berkiatan dengan penyelenggaraan Jenazah meliputi hal-hal yang harus dilakukan oleh orang-orang yang hidup terhadap orang yang baru meninggal; yakni (1) Melepaskan semua pakaian yang melekat pada mayat, (2) Menutupi seluruh badan mayat dengan kain agar auratnya tidak kelihatan oleh orang lain, (3) Jika mata mayat terbuka harus diupayakan agar matanya tertutup (seperti orang tidur), dan (4) Mulut si mayat biasa menganga maka perlu diikat dengan sehelai kain dari dagu hingga kepala sambil membaca do'a dalam hati, (5) Kedua tangan mayat diletakan di atas dadanya.

Ada beberapa hal yang harus dilakukan oleh orang-orang yang hidup terhadap orang yang baru meninggal, sambil menunggu proses memandikan, disunnahkan memperbanyak membaca al-Qur'an surat Yasin untuk jenazah. Memandikan jenazah, mengafani, menshalatkan dan memakamkannya. Kedua ini melanjutkan dan menyempurnakan materi yang pertama yakni kami menjelaskan materi tentang mengkafani jenazah, menyalatkannya. Sedangkan pada sesi ketiga atau hari terakhir pendampingan dan membimbingan pelaksanaan praktik tatacara penyelenggaran jenazah, peserta penyelenggaraan jenazah kami bagi perkelompok untuk mempermudah pelaksanaan kegiatan, kelompok yang menjalankan praktik itu harus melaksanakan tugasnya sesuai instruksi dari tim, misalnya kelompok yang 
memandikan jenazah saat melaksanakan tugas untuk mempraktekan memandikan tiem harus menjalankan tugasnya sesuai instruksi sedangkan kelompok yang lain harus memperhatikan bagaimana cara memandikan jenazah ini begitu selanjutnya. Dalam kegiatan praktik ini peserta diperbolehan untuk bertanya, dan langsung dijawab oleh pembimbing. Dalam pelaksanaan praktik ini para peserta sangat antusias dan sangat ramai serta sangat menarik perhatian sebab mereka mendapatkan pengalaman yang sangat berharga dan sangat penting dalam hidup mereka. Praktik penyelenggaran jenazah ini merupakan pendalaman dari materimateri yang disampaikan pada penjelasan sesi sebelumnya. Yakni yang harus dilakukan saat berhadapan dengan seseorang yang sedang sakaratul maut, mentharakan awal, memandikan, mengafani, menshalatkan dan menguburkan.

Berdasarkan hasil observasi bahwa proses pendampingan yang telah dilakukan selama kegiatan pendampingan dalam penyelenggaraan Jenazah dengan menerapkan metode explicit intruction mengalami peningkatan dalam proses dan hasil dalam penyelenggaraan Jenazah. Berdasarkan hasil analisis bahwa secara umum dalam pelaksanaan pendampingan menyelenggarakan jenazah dengan metode Explicit Intruction terjadi peningkatan pengetahuan dan ketrampilan siswa SMA Ma'arif Pandaan, hal ini ditandai adanya peningkatan dalam pelaksanaan penyelenggaraan Jenazah di SMA Maarif NU Pandaan.

Berdasarkan hasil pengamatan bahwa pelaksanaan kegiatan dampingan praktek penyelenggaraan jenazah cukup direspon baik dan meningkatkan motivasi belajar dan praktik dalam penyelenggaraan Jenazah di SMA Maarif Pandaan, hal ini ditandai dengan aktivitas peserta dalam mengikuti kegiatan penyelenggaraan jenazah di SMA Maarif NU Pandaan sangat berantusias sekali dan merespon terhadap adanya kegiatan pendampingan ini, selain itu adanya ungkapan berterimakasih baik dari guru Agama serta kepala Sekolah karena telah memberikan informasi dan dampingan kepada SMA Maarif NU Pandaan dalam praktek penyelenggaraan jenazah, harapan mereka kepada tim pengabdian jika ada kesempatan lain untuk dihadirkan. 
218 | Pendampingan Praktik Penyelenggaraan Jenazah ...

Dalam konteks implementasi metode explicit instruction dalam penyelenggaraan Jenazah terjadi peningkatan baik dari sisi proses maupun hasil. Ada beberapa hal yang dapat menyebabkan implementasi metode pembelajaran explicit instruction dapat meningkatkan hasil belajar siswa. Pendamping dapat mengendalikan isi materi serta urutan informasi yang diterima oleh siswa sehingga guru dapat mempertahankan fokus apa yang harus dicapai oleh siswa, dapat diterapkan secara efektif dalam kelas besar maupun kecil, menekankan poin-poin penting atau kesulitan-kesuliatan yang mungkin dihadapi siswa sehingga hal-hal tersebut dapat diungkapkan, dapat menjadi cara yang efektif untuk mengajarkan informasi dan pengetahuan faktual yang sangat terstruktur, mengajarkan konsep dan keterampilan-keterampilan yang explicit kepada siswa yang berprestasi rendah, menyampaikan informasi yang banyak dalam waktu yang relatif singkat dan dapat diakses secara setara oleh seluruh siswa, menyampaikan ketertarikan pribadi menganai mata pelajaran (melalui presentasi yang antusias) yang dapat memberikan motivasi ketertarikan dan antusiasme siswa.(Yumiarti, Efrizon, \& Huda, 2018)

\section{Kesimpulan}

Pelaksanaan program pengabdian kepada Masyarakat yang telah dilakukan di SMA Ma'arif NU Pandaan selama satu bulan dari tanggal 14 Januari sampai dengan 14 Februari 2020. Pada program pengabdian kepada Masyarakat ini yang menjadi lembaga Mitra adalah SMA Maarif NU Pandaan. Pelaksanaan pengabdian kepada Masyarakat ini berjalan dengan lancar sesuai rencana dan tujuan yang diharapkan, hal ini dapat terjadi karena adanya kerjasama yang baik dengan lembaga sebagai pihak mitra dampingan. Selain itu pihak sekolah baik kepala sekolah, pegawai, guru maupun siswa/siswi SMA Ma'arif NU Pandaan memiliki komitmen yang baik terhadap pengawalan pelaksaanaan program pendampingan ini. Hasil kegiatan pendampingan yang telah dilakukan dapat meningkatkan proses dan hasil dalam penyelenggaraan Jenazah dengan metode explicit intruction 
terdapat perubahan dan bisa dikatakan berhasil hal ini dibuktikan dengan kondisi siswa yang bersemangat dan hasil penilaian yang baik.

\section{Daftar Pustaka}

Ceri Riyana, dan R. S. (2012). Media Pembelajaran. Bandung: CV Wacana Prima. Huda, M. (2013). Model-Model Pengajaran dan pembelajaran: Isu-Isu Metodis dan paradigmatis. Yogyakarta: Pustaka Pelajar.

Qirana, D. (2008). Penerapan Model Explicit Instruction dalam Memenuhi Kriteria Ketuntasan Minimal (KKM) pada Mata Pelajaran Teknologi Informasi dan Komunikasi. J. Pendidik. FPMIPA UPI.

Yumiarti, D. S., Efrizon, E., \& Huda, A. (2018). Pengaruh Metode Pembelajaran Explicit Instruction Terhadap Hasil Belajar Siswa Pada Mata Pelajaran Pemrograman Web Dinamis Kelas Xi Jurusan Rekayasa Perangkat Lunak (Rpl) Di Smk Negeri 1 Sintuk Toboh Gadang. Jurnal Vocational Teknik Elektronika Dan Informatika, 6(1). 
220 | Pendampingan Praktik Penyelenggaraan Jenazah ... 